\title{
Pediatric nephrology in primary care: the forest for the trees
}

\author{
Donald E. Greydanus ${ }^{1 *}$, Vimal Master Sankar Raj ${ }^{2}$ and Joav Merrick ${ }^{3,4}$ \\ ${ }^{1}$ Department of Pediatric and Adolescent Medicine, Western Michigan University Homer Stryker MD School of Medicine, \\ Kalamazoo, MI, USA, ${ }^{2}$ Department of Pediatric Nephrology, Children's Hospital of Illinois, Peoria, IL, USA, ${ }^{3}$ National Institute \\ of Child Health and Human Development, Jerusalem, Israel, ${ }^{4}$ Office of the Medical Director, Health Services, Division for \\ Intellectual and Developmental Disabilities, Ministry of Social Affairs and Social Services, Jerusalem, Israel
}

Keywords: pediatrics, nephrology, primary care, kidney, public health

\section{Introduction}

The first book on pediatrics in the Western world was published in 1544 AD by Thomas Phaer (1510-1560) - a truly assiduous Renaissance man of sagacity - physician, lawyer, poet, philosopher, and father of English pediatrics (1). However, sustained interest in diseases of children has come over the past two centuries as attention before that was primarily, and certainly continues to be, with diseases of adults $(2,3)$. Prior to this, medical care for children was provided by midwives, families, and family friends (2). As progress was made in various organs of the human, knowledge about the kidneys gradually arose. Much information was gained in both adult and pediatric nephrology in the twentieth century. One concept for the primary care clinician to consider is where is the field of pediatric nephrology going and what is the role of primary care in this regard?

\section{Twenty-First Century: Future Directions}

Azienda Ospedaliero Universitaria

Consorziale Policlinico di Bari, Italy Susan Elizabeth Esposito,

Life University, USA

Unini Odama,

Landmark Nephrology and

Hypertension Clinic, USA

${ }^{*}$ Correspondence:

Donald E. Greydanus

donald.greydanus@med.wmich.edu

As we carefully cast our eyes though the keyhole of science, one can see more wondrous advances in nephrology as this twenty-first century unwinds based on the work of previous scholars (Table 1) $(2,4)$. More understanding will develop in the complex interactions of vitamin D and the kidney based on the 1973 synthesis of $1,25(\mathrm{OH})_{2}$ vitamin D (4-6). Rickets was identified in the first part of the twentieth century and research on this defective disorder of mineralization will reach further progress (4). Mutations in podocyte genes were shown in the twentieth century to lead to renal dysfunction from hereditary podocytopathies that has opened up an active vein of study in this century $(4,7)$. The twentieth century Human Genome Project (HGP) has energized intense inquisition on genetic causes of renal disease and genetic testing in renal disease in this century with work on total human exome capture, next-generation sequencing, gene regulatory networks (GRN), genome-wide association studies (GWAS), the role of micro-RNAs (miRNAs) in renal disease, genotype-based risk prediction, and individualized genetic treatments $(4,8-11)$.

Modern science will continue its hunt for understanding of renal disorders by looking at twentyfirst century progress in cell biology, epigenetics, metabolomics, proteomics, pharmacogenomics, other "omics," integrins, inflammasomes, autophagy, stem cells, biomarkers, and other examples of Research and Development (12-20). At the turn of the twenty-first century, research revealed that the study of proteomics was being used to classify defects in such renal conditions as congenital nephrotic syndrome (NS), renal hypomagnesia, and Alport syndrome variants. Ion channel mutations were identified in the early 1990s as etiologically implicated in various renal tubular syndromes, nephrogenic diabetes, and polycystic renal disease; this erudite exploration will continue (4).

Simultaneous cognizance of diabetes from Areteus of Capadocia (81-138 AD - "melting away of flesh into urine") and renal physiology over the eons have lead to twentieth and now twenty-first 
TABLE 1 | Evolving twenty-first century progress in nephrology.

AIDS nephropathy

Anti-inflammatory disease and treatments

Antecedents of adult renal disease

Continuous ambulatory peritoneal dialysis (CAPD) vs. APD in children

Diabetic nephropathy

Genetic and genomic techniques/genetics (single gene disorders)

Hypertension and the kidney

Ion channel mutations

Molecular and cell biology

Nephrotic syndrome

Others (see text)

Pediatric kidney transplantation and graft rejection

Podocytopathies

Proteomics

Rickets

Stem cell therapies

Tissue engineering and regenerative medicine

Vitamin D and the kidney (proximal tubule interactions and others)

century research on diabetic kidney disease that will advance (21). Cross-over investigations between the current and past centuries include exploration of the cause and management of hypertension and its connection to renal physiology as well as the impact of the twenty-first century epidemic on obesity (22). Another cross-over epidemic from the previous century to the present one that will continue is AIDS/HIV, including AIDS nephropathy that was first identified in the 1980s (23).

Continuous ambulatory peritoneal dialysis (CAPD) in children was identified in the 1970s and 1980s; its usefulness will be studied further now and well into this century - in relation to such issues as risk (i.e., peritonitis) and automated peritoneal dialysis (APD) (24). Challenges and benefits of pediatric renal transplantation will persevere to occupy researchers in pediatric and adult nephrology (25). This exigent endeavor includes protocols for minimal utilization of steroids and calcineurin inhibitors, improved anti-HLA antibodies diagnosis, and innovative methods to reduce early acute rejection and graft loss (25). Transplantation problems continue including donor organ shortage, graft failure, and many complications. Research in the twenty-first century is looking at cell-based tools that utilize tissue engineering and regenerative medicine to allow replacement of dysfunctional renal cells with normally functioning cells and subsequent normalization of renal activity (26).

Research will also advance issues that initiated the field of pediatric nephrology in the latter half of the twentieth century including improved diagnosis and management of acute kidney injury (AKI), polycystic kidney disease, vesicoureteral reflux (VUR), and the NS (27). For example, work continues in AKI with reference to its early identification and its relation to hemodynamic resuscitation protocols. An algorithm has been developed to serve as a beneficial diagnostic tool for primary care clinicians with regard to early diagnosis and management of renal cystic

\section{References}

1. Bloch H. Thomas Phaer, MD (1510-1560): father of English pediatrics. South Med J (1990) 83(6):672-4. doi:10.1097/00007611-19900600000019 disease. Studies are also examining current protocols in VUR diagnosis and management. After hundreds of years of dealing with the NS in medicine, NS remains a complex condition often subject to relapse and remission in most patients despite management in the twenty-first century (27).

\section{Primary Care: A Need for Insightful Information}

The current and future shortage of pediatric nephrologists necessitates steady, rejuvenated information on the pediatric kidney for primary care clinicians as they care for the child and adolescent with renal and genitourinary dilemmas and disorders (28-30). As noted by a number of experts, this shortage of nephrologists, including pediatric nephrologists, will continue into the twentyfirst century (28-30). In view of this shortage and the rapidly increasing knowledge in pediatric nephrology as well understanding indications for referral to pediatric nephrologists in the twenty-first century, useful information aimed at primary care clinicians in these areas becomes increasingly important.

It is easy for a non-nephrologist to become lost in the complexities of renal physiology, diagnosis, and treatment - i.e., to miss the forest for the trees. In this expression, one can see so many trees but not understand they are part of a vast forest and fail to appreciate the forest itself.

As the primary care clinician consider the many details of pediatric nephrology (the "trees") one can fail to appreciate basic concepts that they can manage (the "forest") - as for example - effectively managing potentially benign but common conditions, such as transient proteinuria, orthostatic proteinuria, and microscopic hematuria without proteinuria. If one appreciates that the majority of kidney disease in children relates to hypertension, the primary care physician (PCP) can be energized to persistently and carefully monitor the blood pressure of all of his/her pediatric patients. Early diagnosis of hypertension and careful management of all these patients with the help of consultants is a vital and rewarding task of primary care clinicians and will prevent much renal disease in these pediatric patients. Management of dehydration is also a critical role of clinicians (31). It is important for the PCP to remain familiar with common scenarios in nephrology through conferences and workshops. An interest in this field is important as PCPs will continue to monitor many of these children as the shortage of pediatric nephrologists will continue. The primary care clinician who clearly sees this forest will be of immense help to their pediatric patients and not miss the forest for the trees in pediatric nephrology.

I'm always astonished by a forest. It makes me realize that the fantasy of nature is much larger than my own fantasy. I still have things to learn.

Gunter Grass (1927-2015).

2. Mahnke CB. The growth and development of a specialty: the history of pediatrics. Clin Pediatr (Phil) (2000) 39(12):705-14. doi:10.1177/ 000992280003901204

3. Greydanus DE, Merrick J. Introduction: adolescent medicine. In: Greydanus DE, Patel DR, Omar HA, Feucht C, Merrick J, editors. Adolescent 
Medicine: Pharmacotherapeutics in General, Mental, and Sexual Health. Berlin: De Gruyter (2012). p. 1-7.

4. Chesney RW. The future of pediatric nephrology. Pediatr Nephrol (2005) 20(7):867-71. doi:10.1007/s00467-005-1902-0

5. Shroff R, Knott C, Rees L. The virtues of vitamin D - but how much is too much? Pediatr Nephrol (2010) 25(9):1607-20. doi:10.1007/s00467-010-1499-9

6. Chesney RW. Interactions of vitamin D and the proximal tubule. Pediatr Nephrol (2015). doi:10.1007/s00467-015-3050-5

7. Büscher AK, Weber S. Educational paper the podocytopathies. Eur J Pediatr (2012) 171(8):1151-60. doi:10.1007/s00431-011-1668-2

8. Wuttke M, Schaefer F, Wong CS, Köttgen A. Genome-wide association studies in nephrology: using known associations for data checks. Am J Kidney Dis (2015) 65(2):217-22. doi:10.1053/j.ajkd.2014.09.019

9. Witasp A, Nordfors L, Carrero JJ, Luttropp K, Lindholm B, Schalling M, et al. Genetic studies in chronic kidney disease: interpretation and clinical applicability. J Nephrol (2012) 25(6):851-64. doi:10.5301/jn.5000216

10. Friedhelm H. Genetic kidney diseases. Lancet (2010) 375(9722):1287-95. doi: 10.1016/S0140-6736(10)60236-X

11. Bockenhauer D, Medlar AJ, Ashton E, Kleta R, Lench N. Genetic testing in renal disease. Pediatr Neprhol (2012) 27(6):873-83. doi:10.1007/s00467-011$1865-2$

12. O'Sullivan L, Combes AN, Moritz KM. Epigenetics and developmental programming of adult renal diseases. Pediatr Nephrol (2012) 27(12):2175-82. doi: 10.1007/s00467-012-2108-x

13. Fanos V, Fanni C, Ottonello G, Noto A, Dessi A, Mussap M. Metabolomics in adult and pediatric nephrology. Molecules (2013) 18(5):4844-57. doi:10.3390/ molecules18054844

14. Ho J, Dart A, Rigatto C. Proteomics in acute renal injury - current status and future promise. Pediatr Nephrol (2014) 29(2):163-71. doi:10.1007/s00467-0132415-x

15. Medeiros M, Castaneda-Hernandez G, Ross CJ, Carleton BC. Use of pharmacogenomics in pediatric renal transplant recipients. Front Genet (2015) 6:41. doi:10.3389/fgene.2015.00041

16. Mathews S, Chen X, Pozzi A, Zent R. Integrins in renal development. Pediatr Nephrol (2012) 27(6):891-900. doi:10.1007/s00467-011-1890-1

17. Darisipudi MN, Knauf F. An update on the role of inflammasomes in the pathogenesis of kidney diseases. Pediatr Nephrol (2015). doi:10.1007/s00467015-3153-z

18. De Rechter S, Decuypere JP, Ivanova E, van den Heuvel LP, De Smedt H, Levtchenko E, et al. Autophagy in renal diseases. Pediatr Nephrol (2015). doi: 10.1007/s00467-015-3134-2

19. Yeagy BA, Cherqui S. Kidney repair and stem cells: a complex and controversial process. Pediatr Nephrol (2011) 26(9):1427-34. doi:10.1007/s00467-011$1789-\mathrm{x}$
20. Hartung DA. Biomarkers and surrogate endpoints in kidney disease. Pediatr Nephrol (2015). doi:10.1007/s00467-015-3104-8

21. Tuttle KR, Bakris GL, Bilous RW, Chiang JL, de Boer IH, Goldstein-Fuchs J, et al. Diabetic kidney disease: a report from an ADA consensus conference. Am J Kidney Dis (2014) 64(4):510-33. doi:10.1053/j.ajkd.2014.08.001

22. Wirax AJ, Kaspers PJ, Nauta J, Chinapaw MJ, Kist-van Holthe JE. Pathophysiology of hypertension in obese children: a systematic review. Obes Rev (2015) 16:831-42. doi:10.1111/obr.12305

23. Ramsuran D, Bhimma R, Ramdial PK, Naicker E, Adhikari M, Deonarain J, et al. The spectrum of HIV-related nephropathy in children. Pediatr Nephrol (2012) 27(5):821-7. doi:10.1007/s00467-011-2074-8

24. Akoh JA. Peritoneal dialysis associated with infections: an update on diagnosis and management. World J Nephrol (2012) 1(4):106-12. doi:10.5527/wjn.v1. i4.106

25. Peruzzi L, Amore A, Coppo R. Challenges in pediatric renal transplantation. World J Transplant (2014) 4(4):222-8. doi:10.5500/wjt.v4.i4.222

26. Moon KH, Ko IK, Yoo JJ, Atala A. Kidney diseases and tissue engineering. Methods (2015). doi:10.1016/j.ymeth.2015.06.020

27. Kreeftmeijer-Vegter AR, Dorlo TP, Gruppen MP, de Boer A, de Vries PJ. Population pharmacokinetics of levamisole in children with steroid-sensitive nephrotic syndrome. Br JClin Pharmacol (2015) 80(2):242-52. doi:10.1111/bcp. 12607

28. Weinstein AR, Reidy K, Norwood VF, Mahan JD. Factors influencing pediatric nephrology entry into the workforce. Clin J Am Soc Nephrol (2010) 5(10):1770-4. doi:10.2215/CJN.07071009

29. Primack WA, Meyers KE, Kirkwood SJ, Ruch-Ross HS, Radabaugh CL, Greenbaum LA. The US pediatric nephrology workforce: a report commissioned by the American Academy of Pediatrics. Am J Kidney Dis (2015) 66(1):33-9. doi:10.1053/j.ajkd.2015.03.022

30. Parker MG, Ibrahim T, Shaffer R, Rosner MH, Molitoris BA. The future nephrology workforce: will there be one? Clin J Am Soc Nephrol (2011) 6:1501-6. doi:10.2215/CJN.01290211

31. Friedman A. Fluid and electrolyte therapy: a primer. Pediatr Nephrol (2010) 25(5):843-6. doi:10.1007/s00467-009-1189-7

Conflict of Interest Statement: The authors declare that the research was conducted in the absence of any commercial or financial relationships that could be construed as a potential conflict of interest.

Copyright $\odot 2015$ Greydanus, Master Sankar Raj and Merrick. This is an open-access article distributed under the terms of the Creative Commons Attribution License (CC $B Y$ ). The use, distribution or reproduction in other forums is permitted, provided the original author(s) or licensor are credited and that the original publication in this journal is cited, in accordance with accepted academic practice. No use, distribution or reproduction is permitted which does not comply with these terms. 